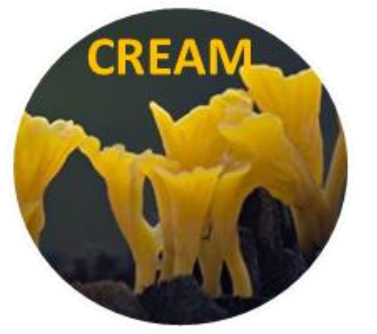

Current Research in Environmental \& Applied Mycology 6 (2): 102-110(2016) ISSN 2229-2225

www.creamjournal.org

Article

CREAM

Copyright $@ 2016$

Doi 10.5943/cream/6/2/4

\title{
Proximate composition and cytotoxicity of single cell protein enriched rich bran
}

\author{
Ganado LS ${ }^{1}$, Undan $\mathrm{JR}^{1}$ and Valentino $\mathrm{MJG}^{1 *}$ \\ ${ }^{1}$ Department of Biological Sciences, College of Arts and Sciences, Central Luzon State University, Science City of Munoz, \\ Nueva Ecija, 3120 Philippines
}

Ganado LS, Undan JR, Valentino MJG 2016 - Proximate composition and cytotoxicity of single cell protein enriched rich bran. Current Research in Environmental \& Applied Mycology 6(1), 102-110, Doi $10.5943 /$ cream/6/2/4

\begin{abstract}
Single cell protein or mycoprotein does not only enrich crude protein content but also enhances the carbohydrate, lipids, minerals, and other nutritional attributes of the substrates. Thus, the conduct of the present study to evaluate the proximate composition (moisture content, crude fat, crude fiber and ash content, total carbohydrates and total energy) of the endophytic fungi treated rice bran.

Nine species of endophytic fungi associated with bamboo (Cladosporium cladosporioides, Aspergillus ochraceus, Aspergillus niger, Aspergillus flavus, Penicillium citrinum, Monascus ruber, Fusarium semitectum, Fusarium sp. 1 and Fusarium sp. 2) were used to improve the proximate composition of the rice bran. Results revealed significant increase in the moisture, crude fiber, crude fat and ash content while decrease in total energy and total carbohydrates were recorded. Fusarium semitectum - treated rice bran obtained the highest moisture content of $10.82 \%$ while the least of 7.83\% was obtained by Penicillium citrinum - treated rice bran. Ash content of rice bran was increased from $19.75 \%$ to $22.90 \%$ by Aspergillus niger. For the crude fat, Fusarium sp. 2 - treated rice bran recorded the highest crude fat of $4.86 \%$ while Fusarium sp 1 registered the highest crude fiber with 27.64\%. All, except Aspergillus ochraceaus and Fusarium sp 1 were found non-cytotoxic at 6 and $12 \mathrm{hrs}$ of incubation depicting their feasibility as safe and nutrient enriched substitute to animal feeds.
\end{abstract}

Key words - ash - crude fat - crude fiber - cytotoxity - moisture rice - bran - single cell protein

\section{Introduction}

Rice bran is the pericarp and germ of rice seeds which constitute $8 \%$ of rice by-product during milling process (Esa et al. 2013). It constitutes about $10 \%$ of rough rice grain which can be a good source of protein, fat and antioxidants. Rice bran has been reported as a potential raw material for the preparation of functional foods or nutraceuticals. In addition, rice bran contained phenolic base compounds and high amounts of vitamins, minerals, proteins and fiber, which can help to lower cholesterol and enact anti-atherogenic activity (Wilson et al. 2002, Kennedy \& Burlingame 2003, Parrado et al. 2006, Esa et al. 2013).

In the Philippines and in other tropical regions, rice bran is used as livestock and animal feeds. Also, several studies had already utilized rice bran as substrate in the production of single cell protein using several fungal species (Anupama \& Ravindra 2001, Oshama \& Ikenobemah 2005, Ravinder el at. 2003, Rao et al. 1993a \& b, Sumantha et al. 2006). Accordingly, single cell protein (SCP) from the microbial biomass is a cheap protein source used as animal feed to the better growth of animals which 
may play an important role to overcome the deficiency of protein (Ravindra \& Anupama 2001, Rajoka et al. 2006). The increase in protein levels obtained is as a result of the bioconversion of the sugars into mycelia protein (Iyayi \& Aderolu 2004). SCP also contains fats, carbohydrates, nucleic acids, vitamins and minerals (Mondal et al. 2012).

During the micropropagation of bamboo, endophytic fungi were found thriving on the eveloping shoots of the plants hence its utilization for the production of single cell protein. Endophytes are found in living tissue of plants and may be a novel and good producers of xylanase, extra cellular cellulose, hemicellulase during fermentation in a desirable substrate. Additionally, based on several studies enzymes are released during the process of fermentation causing degradation of substrates components (Leuchtmann et al. 1992, Suto et al. 2002, Li et al. 2007, Molina et al. 2012).

In the recent study of Valentino et al. 2016, the potentiality of endophytic fungi as sources of single cell protein was revealed. Accordingly, increase in protein content corresponds to enhance proximate composition of the substrate which could be beneficial to animal health and nutrition. Hence, the present study primarily aimed to probe the potentials of the endophytic fungi in enriching the proximate composition of the rice bran. Results of the study would lead to further utilization of these endophytic fungi as single cell protein producers with the ability of enhancing the nutritional attributes of the substrates which can be used as supplement to animal feeds.

\section{Materials and Methods}

Methodology was based from the previous works of Valentino et al. (2015), Paynor et al. (2016) and a continuation of the study of Valentino et al. (2016).

\section{Preparation of Substrates}

One hundred fifty (150) grams of rice bran was placed in a clean bottle and $176 \mathrm{ml}$ of distilled water was added to the rice bran to obtain $60-65 \%$ moisture content. This was covered with plastic and was sterilized at $15 \mathrm{psi}$ at $121^{\circ} \mathrm{C}$ for 1 hour.

\section{Preparation and Inoculation of the Fungal Endophytes}

Endophytic fungi were grown in Potato Dextrose Agar for seven days. Spores were then adjusted to $5.0 \times 10^{6}$ cells per $\mathrm{ml}$ using a haemocytometer. Twenty (20) $\mathrm{ml}$ of the adjusted spore suspension of different endophytic fungi were aseptically transferred to the sterile rice bran. Cultures were covered with plastic and inoculum was allowed to acclimatize in the substrate for 20 days at room temperature.

\section{Harvesting and Drying}

After 20 days of solid state fermentation, the cultures were sterilized at 15 psi for one hour. It was spread in a clean paper individually and was air dried for seven days. Dried samples were pulverized using mortar and pestle. After which, samples were sent to Philippine Carabao Center, Science City of Muñoz, Nueva Ecija for the crude fat, crude fiber, ash, moisture content analysis of the samples.

\section{Proximate Composition}

Moisture content, ash content, crude fat, crude carbohydrates, crude protein and total energy value was based on the guidelines of the Association of Official Analytical Chemist (1995).Total carbohydrates and energy was also determined. Finally, the increase in proximate components of rice bran was computed.

\section{Cytotoxicity Test}

\section{Brine shrimp hatchery set up}

The hatchery vessel was made using a translucent $1.5 \mathrm{~L}$ soft drink plastic bottle wherein the base was cut and hung in the hatchery rack upside-down or vessel like. The aerator (aquarium air 
pump) was connected to the hatchery by creating a hole in the hatchery cap and inserting the air pump rubber tubing inside. An air stone was attached at the tip of the tubing inside the hatchery to maintain a temperature of $28-30^{\circ} \mathrm{C}$, an eighteen $(18)$ - watt fluorescent bulb was placed about 12 inches above the hatchery vessel.

\section{Hatching of brine shrimp eggs}

ARTEMIA HIGH5 brine shrimp eggs were acquired from the Ulang Production of the Crustacean Section, Bureau of Fisheries and Aquatic Resources, Science City of Munoz, Nueva Ecija, Philippines.

The hatchery was filled with saline solution and one gram of brine shrimp eggs was hatched in the saline solution within 48 hours under illumination and with adequate aeration to keep the eggs in suspension until its 48 hours life. The hatched nauplii were then used for the assay.

\section{Cytotoxicity assay}

Using hand lens, active $48 \mathrm{hr}$ old nauplii were harvested and used for the assay. Ten nauplii were transferred into a saline solution. Ten milligram of each treatment was added to $5 \mathrm{ml}$ saline solution which served as the brine shrimp food. Living nauplii were counted at 6 and $12 \mathrm{hrs}$. The mortality of the brine shrimp was computed using the Abbot's mortality formula.

\section{Statistical Analysis}

Data was analyzed using Analysis of Variance (ANOVA) and Comparison Among Means by Duncan's Multiple Range Test (DMRT). All tests of significance were done at 5\% probability levels.

\section{Results and Discussion}

The ability of the endophytic fungi associated with (Cladosporium cladosporioides, Aspergillus ochraceus, Aspergillus niger, Aspergillus flavus, Penicillium citrinum, Monascus ruber, Fusarium semitectum, Fusarium sp. 1 and Fusarium sp. 2) in enhancing the crude protein content of rice bran was revealed in the previous study of Valentino et al. (2016). Thus, the evaluation the proximate composition of the single cell protein enriched rice bran was carried out.

\section{Moisture Content}

Moisture content of the rice bran was significantly increased after the solid state fermentation with nine endophytic fungi (Table 1). The moisture content of rice bran was increased from $7.95 \%$ to $10.82 \%$ upon treated with Fusarium semitectum. Results can be attributed to the presence of the endophytic fungi performing its degradative activities (Egbebi et al. 2007, Oladele \& Osipitan, 2011). Similarly, Christensen (1957) mentioned that increase in storage fungi population will increase production of carbon dioxide and free acids. Accordingly, fungi produce carbon dioxide and water resulting to increase on the moisture content of the substrate (Chutmanop et al. 2008).

Increase in moisture content of the rice bran could be of significance since this will provide a medium for the transport of dissolved nutrients required for the metabolic and physiological activities of organisms that would lead to a better nutrition and health of the animal. Additionally, increase in moisture content showed a linear increasing effect on the biodegradation rate of organic material (Liang et al. 2003, Pommier et al. 2008).

\section{Ash}

Ash shows the total mineral content of the feed and the remains of minerals after being completely burned. Though is not digestible by animals however seven major and six trace minerals are known to be essential to their health. Minerals are needed to form skeletal structures, for digestion, and in metabolic processes within the body. Although trace minerals are required in very small amounts, adequate levels are just as important as adequate amounts of the major minerals. According to Chutmanop (2008) rice bran contains minerals such as potassium, phosphorus and calcium in considerable amounts. 
Table 1 Moisture content of the fungal enriched rice bran

\begin{tabular}{llc}
\hline Treatments & Moisture & $\begin{array}{c}\% \text { increase in moisture } \\
\text { content }\end{array}$ \\
\hline Uninoculated Rice Bran & $7.95^{\mathrm{a}}$ & 11.57 \\
Aspergillus flavus - treated rice bran & $8.87^{\mathrm{d}}$ & 24.40 \\
Aspergillus niger - treated rice bran & $9.89^{\mathrm{e}}$ & 9.56 \\
Aspergillus ochraceus - treated rice bran & $8.70^{\mathrm{cd}}$ & 8.55 \\
Clasdosporium cladosporioides - treated rice bran & $8.63^{\mathrm{c}}$ & 8.68 \\
Monascus ruber - treated rice bran & $8.64^{\mathrm{c}}$ & 0 \\
Penicillium citrinum - treated rice bran & $7.83^{\mathrm{a}}$ & 36.10 \\
Fusarium semitectum - treated rice bran & $10.82^{\mathrm{f}}$ & 4.03 \\
Fusarium sp. 1 - treated rice bran & $8.27^{\mathrm{b}}$ & 10.82 \\
Fusarium sp. 2 - treated rice bran & $8.81^{\mathrm{cd}}$ & \\
\hline
\end{tabular}

*Treatments with the same letters are not significantly different

Ash content of the evaluated substrates (Table 2) were noticeably higher than the untreated rice bran ranging from $19.75 \%$ ( Fusarium semitectum) to $22.90 \%$ (Aspergillus niger) which were significantly higher than the untreated rice bran. Thus, endophytic fungi contribute to the increase of ash content of the rice bran which could aid in animals' bone formation and other other important functions, including formation of blood cells, blood clotting, enzyme activation, and energy metabolism and for proper muscle function.

Similar results were obtained by Kupski et al. (2012) during the fermentation of rice bran inoculated with A. niger. Also, Deraz \& Ismail (2001) and El-Ashry et al. (2003) observed an increase in crude protein and ash content of roughages. Consequently, Johnson \& Parsons (1997) revealed that high ash products contained more calcium and phosphorus than the low ash products.

Table 2 Ash content of the fungal enriched rice bran

\begin{tabular}{llc}
\hline Treatments & Ash & \% increase in ash \\
\hline Uninoculated Rice Bran & $19.05^{\mathrm{a}}$ & 13.70 \\
Aspergillus flavus - treated rice bran & $21.66^{\mathrm{de}}$ & 20.21 \\
Aspergillus niger - treated rice bran & $22.90^{\mathrm{g}}$ & 14.96 \\
Aspergillus ochraceus - treated rice bran & $21.90^{\mathrm{ef}}$ & 7.09 \\
Clasdosporium cladosporioides - treated rice bran & $20.40^{\mathrm{c}}$ & 17.17 \\
Monascus ruber - treated rice bran & $22.32^{\mathrm{f}}$ & 13.39 \\
Penicillium citrinum - treated rice bran & $21.60^{\mathrm{de}}$ & 3.67 \\
Fusarium semitectum - treated rice bran & $19.75^{\mathrm{b}}$ & 15.70 \\
Fusarium sp. 1 - treated rice bran & $22.04^{\mathrm{ef}}$ & 11.03 \\
Fusarium sp. 2 - treated rice bran & $21.14^{\mathrm{d}}$ & \\
\hline
\end{tabular}

*Treatments with the same letters are not significantly different

\section{Crude Fat}

A necessity in enriching the crude fat of rice bran and other animal feeds is beneficial for the absorption of the fat-soluble vitamins A, D, E, and K. In addition to its role in nutrition, fat is added to feed to reduce grain dust. Fat addition also improves the palatability of feed.

Crude fat of the fungal enriched rice bran was determined and presented in Table 3. Results showed that Fusarium sp. 2 - treated rice bran obtained the highest crude fat of $4.86 \%$ followed by Monascus ruber and Fusarium semitectum - treated rice bran with 4.67 and $4.62 \%$, respectively. Meanwhile, uninoculated rice bran had the least crude fat of $3.60 \%$ followed by Aspergillus flavus - 
treated rice bran of $4.12 \%$. Findings in the recent study can be due to the ability of fungi to utilize crude glycerol as an alternative to conventional carbon substrates for growth and lipid production (Marchand 2005). Additionally, as stated in the study of Akpinar - Bayizit et al. (2014) Fusarium species have potential to utilize numerous agro-industrial residues with prolific mycelial growth and production of essential fatty acids such as Linoleic Acid and Alpha-linolenic Acid. Fusarium sp can accumulate up to $78 \%$ of the total fatty acids as unsaturated fats (Arzu et al. 2014).

Table 3 Crude fat content of the fungal enriched rice bran

\begin{tabular}{llc}
\hline Treatments & Crude Fat & $\begin{array}{c}\text { \% increase in crude fat } \\
\text { content }\end{array}$ \\
\hline Uninoculated Rice Bran & $3.60^{\mathrm{a}}$ & 14.44 \\
Aspergillus flavus - treated rice bran & $4.12^{\mathrm{b}}$ & 22.78 \\
Aspergillus niger - treated rice bran & $4.42^{\mathrm{bc}}$ & 20.28 \\
Aspergillus ochraceus - treated rice bran & $4.33^{\mathrm{bc}}$ & 23.33 \\
Clasdosporium cladosporioides - treated rice bran & $4.44^{\mathrm{bc}}$ & 29.72 \\
Monascus ruber - treated rice bran & $4.67^{\mathrm{bc}}$ & 17.78 \\
Penicillium citrinum - treated rice bran & $4.24^{\mathrm{b}}$ & 28.33 \\
Fusarium semitectum - treated rice bran & $4.62^{\mathrm{bc}}$ & 22.78 \\
Fusarium sp. 1 - treated rice bran & $4.42^{\mathrm{bc}}$ & 35.00 \\
Fusarium sp. 2 - treated rice bran & $4.86^{\mathrm{c}}$ & \\
\hline
\end{tabular}

*Treatments with the same letters are not significantly different

\section{Crude Fiber}

Crude fiber is the insoluble carbohydrate remaining in the feed analysis process after the sample is boiled in weak acid and alkali. It is made up of plant structural carbohydrates such as cellulose, lignin and hemicelluloses (, Bach Knudsen 2001, Lupton 2010, Esa et al. 2013).

The highest crude fiber with $27.64 \%$ was recorded by Fusarium sp 1 - treated rice bran followed by Fusarium semitectum - treated rice bran with $22.15 \%$ and Aspergillus niger - treated rice bran with $21.58 \%$ while the uninoculated rice bran had the least of $17.78 \%$ (Table 4). These greatly indicate the ability of the eight endophytic fungi in increasing the crude fiber content of the rice bran. Results coincide with the study of Kakde \& Chavan (2011) wherein crude fiber content of oilseed was increased using Curvularia lunata, Curvularia pellescens, Macrophomina phaseolina, Rhizopus stolonifer and Penicillium digitatum including Fusarium due the remnants of fungal mycelia in the substrates.

Animal feeds with high fiber content impart superior physical tone stamina to animals since fiber speeds up the process of digestion by improving peristalsis (Farrelly 1984, Okaraonye \& Ikewuchi, 2009). Increasing the insoluble fiber content of the diet has resulted in a reduced length of the small intestine and decreased proventricular weight in some cases of birds (Jiménez-Moreno et al., 2009). In grower-finisher pigs, high fibre diets are known to increase viscera mass, and thereby reduce dressing percentage at slaughter. Overall, high fibre diets have a lower energy digestibility and a lower feed efficiency is thus expected (Zijlstra \& Beltranena 2014). Furthermore, Anuga et al. (1989) stated that feeding the high fiber diet resulted in lower absolute and relative liver and kidney weights, lower absolute large intestine weight and higher absolute and relative stomach weights than the high protein diet.

\section{Total carbohydrates and Total energy of the fungal enriched rice bran}

The major carbohydrates in bran are cellulose and hemicellulose which give the thick cell wall of the pericarp, the seed coat and the aleurone layer (Juliano \& Bechtel 1985). Whereas, energy is the major dietary element that is responsible for the different utilization of nutrients and thereby the productivity and gain of an animal (Hosseini et al. 2008). 
Table 4 Crude fiber content of the fungal enriched rice bran

\begin{tabular}{lll}
\hline Treatments & Crude Fiber & \%increase crude fiber \\
& & \\
\hline Uninoculated Rice Bran & $17.78^{\mathrm{a}}$ & 14.06 \\
Aspergillus flavus - treated rice bran & $20.28^{\mathrm{bc}}$ & 21.37 \\
Aspergillus niger - treated rice bran & $21.58^{\mathrm{cd}}$ & 7.93 \\
Aspergillus ochraceus - treated rice bran & $19.19^{\mathrm{b}}$ & 7.82 \\
Clasdosporium cladosporioides - treated rice bran & $19.17^{\mathrm{b}}$ & 14.40 \\
Monascus ruber - treated rice bran & $20.34^{\mathrm{bc}}$ & 6.58 \\
Penicillium citrinum - treated rice bran & $18.95^{\mathrm{ab}}$ & 24.58 \\
Fusarium semitectum - treated rice bran & $22.15^{\mathrm{d}}$ & 55.46 \\
Fusarium sp. 1 - treated rice bran & $27.64^{\mathrm{e}}$ & 20.81 \\
Fusarium sp. 2 - treated rice bran & $21.48^{\mathrm{cd}}$ & \\
\hline
\end{tabular}

* Treatment means with the same letter are not significantly different

Decrease in total carbohydrates and total energy of rice bran was observed upon inoculation of the fungal endophytes. Uninoculated rice obtained the highest total carbohydrates of 59.87, followed by Cladosporium cladosporioides - treated rice bran of 56.94 while Aspergillus niger - treated rice bran obtained the least with 52.16. In addition, all treatments were statistically lower than the uninoculated rice bran. Similarly, decrease in total energy was recorded in all fungal enriched rice bran. Uninoculated rice bran obtained the highest with 310.00 while Aspergillus niger - treated rice bran obtained the least total energy 290.94. Significant decrease in carbohydrates and total energy can be attributed to the increase in proximate composition of the endophytic fungi treated rice bran.

Table 4 Total carbohydrates and energy of the fungal enriched rice bran

\begin{tabular}{lll}
\hline Treatments & Carbohydrates & Total Energy \\
& & \\
\hline Uninoculated Rice Bran & $59.87^{\mathrm{a}}$ & $310.00^{\mathrm{a}}$ \\
Aspergillus flavus - treated rice bran & $54.89^{\mathrm{f}}$ & $298.48^{\mathrm{f}}$ \\
Aspergillus niger - treated rice bran & $52.16^{\mathrm{i}}$ & $290.94^{\mathrm{i}}$ \\
Aspergillus ochraceus - treated rice bran & $54.82^{\mathrm{g}}$ & $299.25^{\mathrm{g}}$ \\
Clasdosporium cladosporioides - treated rice bran & $56.94^{\mathrm{b}}$ & $306.08^{\mathrm{b}}$ \\
Monascus ruber - treated rice bran & $54.12^{\mathrm{j}}$ & $299.51^{\mathrm{j}}$ \\
Penicillium citrinum - treated rice bran & $56.14^{\mathrm{c}}$ & $303.48^{\mathrm{c}}$ \\
Fusarium semitectum - treated rice bran & $54.78^{\mathrm{h}}$ & $300.82^{\mathrm{h}}$ \\
Fusarium sp. 1 - treated rice bran & $55.08^{\mathrm{d}}$ & $300.86^{\mathrm{d}}$ \\
Fusarium sp. 2 - treated rice bran & $55.02^{\mathrm{e}}$ & $304.50^{\mathrm{e}}$ \\
\hline
\end{tabular}

* Treatment means with the same letter are not significantly different

\section{Cytotoxicity Assay}

Cytotoxicity of protein- enriched rice bran was performed to determine the feasibility of the treated rice bran as substitute to animal feeds since filamentous fungi are known to produce mycotoxins. Mycotoxins are secondary metabolites produced by fungi colonizing cereal grains in the field and in storage and are harmful to both humans and animals (Bennett \& Richard 1996).

As showed in table 4,0\% mortality rate was recorded in all treatments at 6 hrs of incubation. However, at $12 \mathrm{hrs}$ of incubation higher rate of mortality was observed. Aspergillus ochraceus and Fusarium sp 1- treated rice bran had the highest percentage of mortality of $16.67 \%$ followed by Cladosporium cladosporioides - treated rice bran of $13.13 \%$. Meanwhile, $0 \%$ mortality rate was recorded in Aspergillus flavus - treated rice bran followed by the uninoculated rice bran with 3.33\%. 
Statistical analysis revealed that only Aspergillus ochraceus and Fusarium sp. 1 - treated rice bran were significantly higher than the untreated rice bran. This suggest that among all the endophytic fungi used, only Aspergillus ochraceaus and Fusarium sp 1 have the potentiality of being toxic and the rest can be used as safe substitute to animal feeds.

Toxicity of endophytic fungi-treated rice bran could be due to the presence of mycotoxins. infection of cereal grains with Fusarium species can cause contamination with mycotoxins that affect human and animal health Mycotoxins can be carcinogenic, mutagenic, genotoxic, teratogenic, neurotoxic, and oestrogenic, including reproductive and developmental toxicity (Esjardins et al. 2000, Koppen et al. 2010).

Table 4 Mean percentage of brine shrimp mortality

\begin{tabular}{lll}
\hline \multicolumn{1}{c}{ Treatment } & $\mathbf{6 h r s}$ & $\mathbf{1 2 h r s}$ \\
\hline Uninoculated Rice Bran & 0.00 & $3.33^{\mathrm{ab}}$ \\
Aspergillus flavus - treated rice bran & 0.00 & $0.00^{\mathrm{a}}$ \\
Aspergillus niger - treated rice bran & 0.00 & $10^{\mathrm{abc}}$ \\
Aspergillus ochraceus - treated rice bran & 0.00 & $16.67^{\mathrm{c}}$ \\
Clasdosporium cladosporioides - treated rice bran & 0.00 & $13.13^{\mathrm{bc}}$ \\
Monascus ruber - treated rice bran & 0.00 & $0.00^{\mathrm{a}}$ \\
Penicillium citrinum - treated rice bran & 0.00 & $13.33^{\mathrm{bc}}$ \\
Fusarium semitectum - treated rice bran & 0.00 & $10^{\mathrm{abc}}$ \\
Fusarium sp. 1 - treated rice bran & 0.00 & $16.67^{\mathrm{c}}$ \\
Fusarium sp. 2 - treated rice bran & 0.00 & $13.13^{\mathrm{bc}}$ \\
\hline
\end{tabular}

* Treatment means with the same letter are not significantly different

\section{Conclusion}

The potentials of the nine endophytic fungi in enhancing the proximate composition of the rice bran were clearly demonstrated in the study, making the rice bran a more nutritious animal feeds. Additionally, seven of the single cell protein enriched rice bran (Cladosporium cladosporioides, Aspergillus ochraceus, Aspergillus niger, Aspergillus flavus, Penicillium citrinum, Monascus ruber, Fusarium semitectum, Fusarium sp. 1 and Fusarium sp. 2) have non cytotoxic effects and could be use as safe substitute to animal feeds after further intensive in vitro and in vivo testing with live animals.

\section{References}

Akpinar-Bayizit, Ozcan T, Yilma-Ersan L, Basogly Fikri. 2014 - Single cell oil (SCO) production by Fusarium species using cheese whey as a substrate, 64 (2), $111-118$.

Alagarsamy Sumantha A, Paul Deepa P, Sandhya C, Szakacs G, Soccol CR, Pandey A. 2006 - Rice bran as a substrate for proteolytic enzyme production. Brazilian Archives of Biology and Biotechnoogy, 49(5), $843-851$.

Anupama, Ravindra P. 2001 - Studies on production of single cell protein by Aspergillus niger in solid state fermentation of rice bran. Brazilian Archives of Biology and Technology, 44(1).

Arzu A, Tulay O, Lutifye Y, Fikri B. 2014 - Cheese whey and single cell oil production. Mljekarstvo, 64, 111.

Association of Official Analytical Chemists. 1995 - Official Methods of Analysis of the Association of Official Analytical Chemists, 16th edition, Arlington, USA.

Bennet B, Richard J. 1996 - Influence ofProcessing on Fusarium Mycotoxins in Contaminated Grains. Supplied by U.S. Dept of Agriculture National Center for Agricultural.

Christensen CM. 1957 - Deterioration of stored grains by Fungi The Botanical Review, 23(2), 108 134. 
Chutmanop J, Chuichulcherm S, Chisti Y, Srinophakun P. 2008 - Protease production by Aspergillus oryzae in solid-state fermentation using agroindustrial substrates. Journal of Chemical Technology and Biotechnology J Chem Technol Biotechnol, 83, 1012 - 1018.

Deraz TA, Ismail H. 2001 - Cotton stalks treated with white-rot fungi for feeding sheep. Egyptian J. Nutrition and feeds, 4(Special Issue): 423 - 434.

Egbebi AO, Anibijuwon II, Fagbohun ED. 2007 - Fungi associated with dry cocoa beans during storage in Ekiti State, Nigeria. Pak. J. Nutr. In press.

El-Ashry MA, Kholif AM, Fadel M, El-Alamy HA, El- Sayed HM, Kholif SM. 2003 - Effect of biological treatments on chemical composition in vitro and in vivo nutrients digestibilities of poor quality roughages. Egyptian J. Nutrition and Feeds, 6 (2): 113 - 126.

Esa NM, Ling TB, Peng LS. 2013 - By-products of Rice Processing: An Overview of Health Benefits and Applications. J Rice Res , 1: 107.

Iyayi EA, Aderolu AZ. 2004 - Enhancement of the feeding values of some agro- industrial by-products for laying hens after their solid state fermentation with Trichoderma viride. Afr. J. Biotech. 3 , $182-185$.

Johnson M, Parsons C. 1997 - Effects of Raw Material Source, Ash Content, and Assay Length on Protein Efficiency Ratio and Net Protein Ratio Values for Animal Protein Meals. Department of Animal Sciences, University of Illinois, Urbana, Illinois 61801. Poultry Science 76:1722-1727.

Juliano, B.O. and Bechtel, D.B. (1985) - The grain and its gross composition. In: Rice: Chemistry and Technology p. 17-57. Los Banos, Laguna: IRRI.

Kakde RB, Chavan AM. 2011 - Deteriorative changes in oilseeds due to storage fungi and efficacy of botanicals Current Botany 2(1), $17-22$.

Kennedy G, Burlingame B. 2003- Analysis of food composition data on rice from a plant genetic resources perspective. Food Chemistry, 80, 589-596.

Koppen R, Koch M, Siegel D, Merkel S, Maul R, Nehls I. 2010 - Determination of mycotoxins in foods: current state of analytical methods and limitations. Applied Microbiology and Biotechnology, 86, 1595e1612.

Kupski L, Cipolatti E, Da Rocha M, Dos Santos OM, Soares L, Furlong E. 2012 - Solid-state fermentation for the enrichment and extraction of proteins and antioxidant compounds in rice bran by Rhizopus oryzae. Brazilian Archives of Biology and Technology.

Hosseini SM, et.al. 2008 - Effect of different energy levels of diet on feed efficiency, growth rate and carcass characteristics of fattening lambs. J. of Anim. \& VetAdv., 7(12): 1551 - 1554.

Leuchtmann A, Petrini O, Petrini LE, Carroll GC. 1992 - Isozyme polymorphism in six endophytic Phyllosticta species. Mycological Research 96, 287-294.

Li W, Zhou J, Lin Z, Hu Z. 2007 - Study on fermentation condition for production of huperzine A from endophytic fungus 2F09P03B of Huperzia serrata. Chinese Medicinal Biotechnology. 2, $254-259$.

Liang C, Das KC, McClendon RW. 2003 - The influence of temperature and moisture contents regimes on the aerobic microbial activity of a biosolids composting blend. Bioresource Technol.

Molina G, Pimentel M, Bertucci T, Pastore G. 2012 - Application of fungal endophytes in biotechnological processes. Chemical engineering transactions.

Mondal AK, Sengupta S, Bhowal J, Bhattacharya DK. 2012 - Utilization of fruit wastes in producing single cell protein.International Journal of Science, Environment and Technology, 1(5), 430 438

Oladele OO, Osiptan AA. 2011 - Deterioration of dried maize (Zea mays) stored under different temperatures by fungi. Journal of Biological Sciences and Bioconservation 3, $11-15$.

Oshoma C, Ikenebomeh M. 2005 - Production of Aspergillus niger Biomass from Rice Bran. Pakistan Journal of Nutrition, 4 (1), $32-36$.

Parrado J, Miramontes E, Jover M, Gutierres J, Collantes de Teran L, Bautista J. 2006 - Preparation of a rice bran enzymatic extract with potential use as functional food. Food Chem, 98:742 - 8. 
Paynor KA, David ES, Valentino MJG. 2016 - Endophytic fungi associated with bamboo as possible sources of single cell protein using corn cob as a substrate. Mycosphere, 7 (2), 139-147.

Pommier SD, Chenu M, Quintard, Lefebvre X. 2008 - Modelling of moisture-dependent aerobic degradation of solid waste. Waste Manage., 28: 1188-1200.

Rajoka MI, Khan SH, Jabbar MA, Awan MS, Hashmi AS. 2006 - Kinetics of batch single cell protein production from rice polishings with Candida utilis in continuously aerated tank reactors. Bioresour Technol, 97, 1934-1941.

Rao PV, Jayaraman K, Lakshmanan CM. 1993a - Production of lipase by Candida rugosa in solidstate fermentation. 1: determination of significant process variables. Process Biochem., 28, 385 -389 .

Rao PV, Jayaraman K, Lakshmanan CM. 1993b - Production of lipase by Candida rugosa in solidstate fermentation. 2: Medium optimization and effect of aeration. Process Biochem., 28, 391 395.

Ravinder R, Rao LV, Ravindra P. 2003 - Studies on Aspergillus oryzae Mutants for the Production of Single Cell Proteins from Deoiled Rice Bran. Food Technol. Biotechnol. 41 (3), 243-246.

Suto M, Takebayashi M, Saito K, Tanaka M, Yokota A, Tomita F. 2002 - Endophytes as Producers of Xylanase, Journal of BioScience and Bioengineering 93, 88-90.

Valentino MJG, Kalaw SP, Galvez CT, Reyes RG. 2015 - Mycota of distillery yeast sludge as source of single cell protein. Mycosphere 6(3), 241-247.

Valentino MJG, Ganado LS, Undan JR. 2016 - Single cell protein potential of endophytic fungi associated with bamboo using rice bran as substrate. Advances in Applied Science Research $7(3), 68-72$.

Wilson TA, Idreis HM, Taylor CM, Nicolosi RJ. 2002 - Whole fat rice bran reduces the development of early aortic atherosclerosis in hypercholesterolemic hamsters compared with wheat bran. Nutr Res 22, 1319-1332. 